\title{
DIAGNOSIS FROM CELLS
}

\author{
BY \\ J. BAMFORTH AND G. R. OSBORN \\ From King's College Hospital, London, and Derbyshire Royal Infirmary, Derby
}

\begin{abstract}
"When we recognize what our teachers and leaders accomplished without present-day methods, we will do well to bow our heads deeply before them."-Gierke (1884).
\end{abstract}

The methods used by Virchow which led to his work on cellular pathology are more akin to those of the cytologist than the morbid anatomist. The year 1858 is also notable for the first satisfactory staining of a histological section by Joseph von Gerlach (Fig. 1), as the result of a fortunate accident (Gerlach, 1858a and b). One evening, thanks to an oversight, he left cerebellum fixed in potassium bichromate in a very dilute solution of ammonia carmine. The following day the sections showed much better differentiation of nerve cells and fibres than had ever been seen before. Twenty-five years later Gierke wrote a history of staining to celebrate Gerlach's discovery. Gierke believed that Gerlach was the first to stain a section, although so much good work had been done earlier that now it is not easy to say which advances actually came from Gerlach's discovery.

Earlier work of great value included that of Corti, who in 1851 wrote " Reserches sur l'organe de l'ouie des mammifères." In 1854 Hartig (1854, $a, b$, and c) found that the nucleus of a cell stains only after it is dead, and that the granules of chlorophil have an affinity for carmine, and in 1849 Goeppert and Cohn used carmine and madder to make cell contents more visible. Hill's (Fig. 2) remarkable work (1770) included the use of maceration, fixation (spirits of wine), mordants (alum, sugar of lead), metallic impregnation (quicklime and orpiment in succession to stain stems brown), and stains (cochineal and boiling green sealing wax). Finally the greatest credit must go to Anthony van Leeuwenhoek (1719), the discoverer of the microscope, who compared the muscles of a fat and a thin cow after staining with crocus (saffron) macerated in spirits of wine. He tells us that he prepared very thin sections so that they were quite transparent. This experiment was described in a letter to the Royal Society dated August 21, 1714, but was not published for five years. It is therefore more accurate to say that
Gerlach was the first to popularize histological methods in morbid anatomy.

Diagnostic cytology is the senior science. Virchow and his pupils used both cytology and histology, and a number of eminent pathologists, including Dudgeon and Ewing, continued this habit until recent times. The majority of pathologists, however, abandoned cytology and even denied it any place in diagnostic methods. So Dürck (1904) wrote:

"Hence there is no such thing as a "carcinoma cell' or a ' sarcoma cell'; the type of the tumour, whether it be epithelial, connective tissue, or mixed, can be determined positively only by the arrangement of the cells with regard to one another. For this reason extreme caution is necessary in giving an opinion on the character of a tumour from an examination of isolated tumour-cells."

Gerlach, however, found no opposition between cytology and histology, for to him they were different ways of looking at the same problem.

Before considering the remarriage of cytology and histology which began with the publication of the monograph by Papanicolaou and Traut in 1943, we should look at the work of some of those in England and the United States who kept the study of cytology alive during its dark days.

Lionel S. Beale (Fig. 3) was professor of medicine at King's College Hospital, London. In 1854 he wrote an outstanding book, The Microscope in Medicine, of which a fourth edition appeared in 1878. In it he states:

"The people want the practical doctor, not the person who always has his eye at the end of a microscope, or is continually fishing for new facts in the excretions of the sick. ... Nevertheless, the opinion that the nature of disease should be thoroughly investigated seems to be gaining ground. ... But surely it would be right if rich bodies like Guy's, Saint Thomas's, and Bartholomew's took the lead in this matter. ... I I fear it will be difficult indeed to convince the authorities who have command of the purse."

Beale thought a pathologist could be obtained for $£ 100$ p.a. King's College appears to have been the only hospital with a side-room laboratory. It owed that entirely to Beale, and his book is the outcome of lectures delivered there in 1853 . Beale gives a full account of the methods then in 


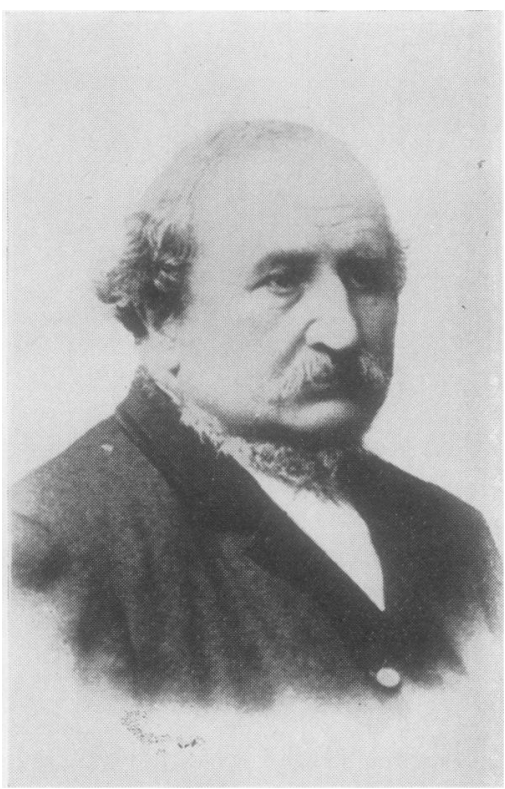

FIG. 1.-Joseph von Gerlach (1820-96), Professor of Physiology and Anatomy in the University of Erlangen. (Photograph given by Professor K. Fr. Bauer, Director of the Institute of Anatomy, University of Erlangen.)

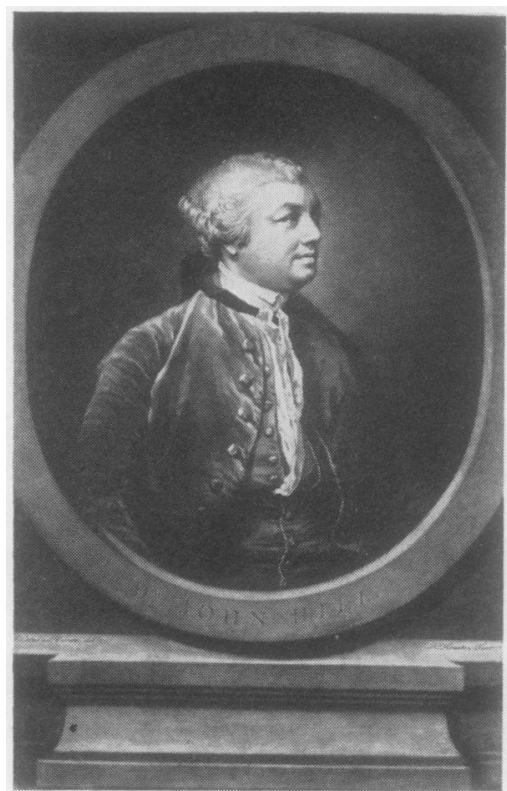

FIG. 2.-Sir J. Hill (1716-75), from the mezzotint by Houston after Coates. The impression is in the British Museum.

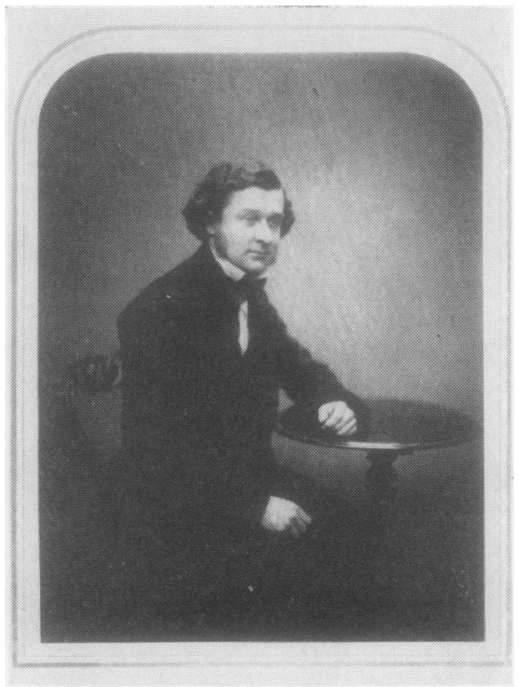

FIG. 3.-L. S. Beale (1828-1906), from an original photograph in the possession of and copyright by the Wellcome Historical Medical Library. 
use for examining tissues. They were teased out in water and other fluids with the aid of a dissecting microscope. Frozen sections were usually cut with the help of nitrous oxide capsules, which were preferred to carbon dioxide snow because they were in ready supply for dentists. Later ether and ethyl chloride were used for freezing. Staining was at first with ammonia carmine, and Beale credits Gerlach with being the first to use this. Hardening and preserving agents used included alcohol, glycerine, carbolic acid, chloride of calcium, and chromic acid. Mounting was in gum damar or Canada balsam, but aqueous mounts were also used. It is most unfortunate that Beale's observations on discharges from the uterus and vagina have been forgotten. He knew of the Trichomonas vaginae described by Donné (1836) in cases of leucorrhoea, a discovery which made Donné the first to describe a living organism in pathological conditions. Beale appears to have agreed with those who considered this parasite "merely a cell of ciliated epithelium from the uterus." This is indeed curious because Beale insisted on the examination of vaginal mucus in a pure state and gives full instructions for warming slides. "In cases of cancer of the uterus, we should expect to meet with cancer cells in the discharges." He illustrates uterine squamous careinoma cells (Fig. 4) in the urine of a woman with advanced carcinoma, and describes the findings in adenocarcinoma: "Villous processes, with loops of vessels, and the modified epithelial coverings." He also describes the "modern" scrape technique :

"In many cases it is not difficult to remove a little of the softened cancerous matter upon the extremity of the sponge used in vaginal examinations. In this way a much better chance of meeting with entire cancer cells is afforded than by examining the urine."

He gives a drawing of cancer cells in the sputum (Fig. 5). Perhaps Beale used his microscope too freely, for giant cells and non-nucleated red blood cells made him disbelieve much of the cell theory. He "proved" in demonstrations to the Royal College of Physicians in 1861 that cells arise when the outer part of the primitive mass of " bioplasm " dies, so giving rise to the cell membranes.

About the year 1925 Professor L. S. Dudgeon (Fig. 6) at St. Thomas's Hospital, London, began to take an increasing interest in cytology. Cells, both innocent and malignant, from tissues and organs in various parts of the body were carefully studied. In collaboration with Patrick (1927) he published a paper on "A New Method for the
Rapid Microscopical Diagnosis of Tumours," and later (1934) with Barrett on "The Examination of Fresh Tissues by the Wet-film Method." In this second paper the method was shown to be applicable to the study of pathological processes in general. Dudgeon and his colleagues achieved considerable success with the wet-film method, and the results obtained in the diagnosis of tumours compared very favourably with those from examination of paraffin sections.

A simple technique was employed. The tissue removed at operation, fresh and unfixed, was incised as soon as possible and the cut surface scraped with a scalpel. A film was made from the juice so obtained, and fixed immediately while still wet in Schaudinn's solution, stained with haemalum and eosin, and mounted in Canada balsam. The whole process could be completed in 10 to 15 minutes, and the intimate details of the structure of the nucleus and cytoplasm were shown far more clearly than in paraffin sections.

This method of examination for the detection of malignancy was obviously capable of wide application. It could be used in the operating theatre instead of a frozen section for the examination of a biopsy specimen, and in the out-patient department in the diagnosis of lesions of the skin or mouth. It was Dudgeon's custom to examine a wide variety of specimens by this methodsputum, faeces, pleural fluid-and on one occasion, in examining a film of sputum, he observed under the microscope a clump of cells which he immediately recognized as malignant. With the collaboration of C. H. Wrigley (1935) he instituted, for the first time, a systematic examination of sputa from cases of suspected lung cancer and demonstrated that malignant cells could be identified in a large proportion of the cases afterwards shown to be malignant, a procedure since confirmed by many workers in different countries. He then began to turn his attention to the examination of pleural and peritoneal fluids, stomach washings, etc., but his untimely death at the outbreak of the second world war unfortunately put an end to these activities.

Cytology and frozen section are not really rival methods for giving the surgeon a rapid answer when the patient is on the operating table. They reveal different aspects and ideally should be used together in every case. Cytology gives an excellent high-power view of the tumour cells but does not reveal their behaviour. Frozen section gives a somewhat crude low-power view, good enough for the accurate diagnosis of nearly all breast lesions. It shows the type of tumour and 


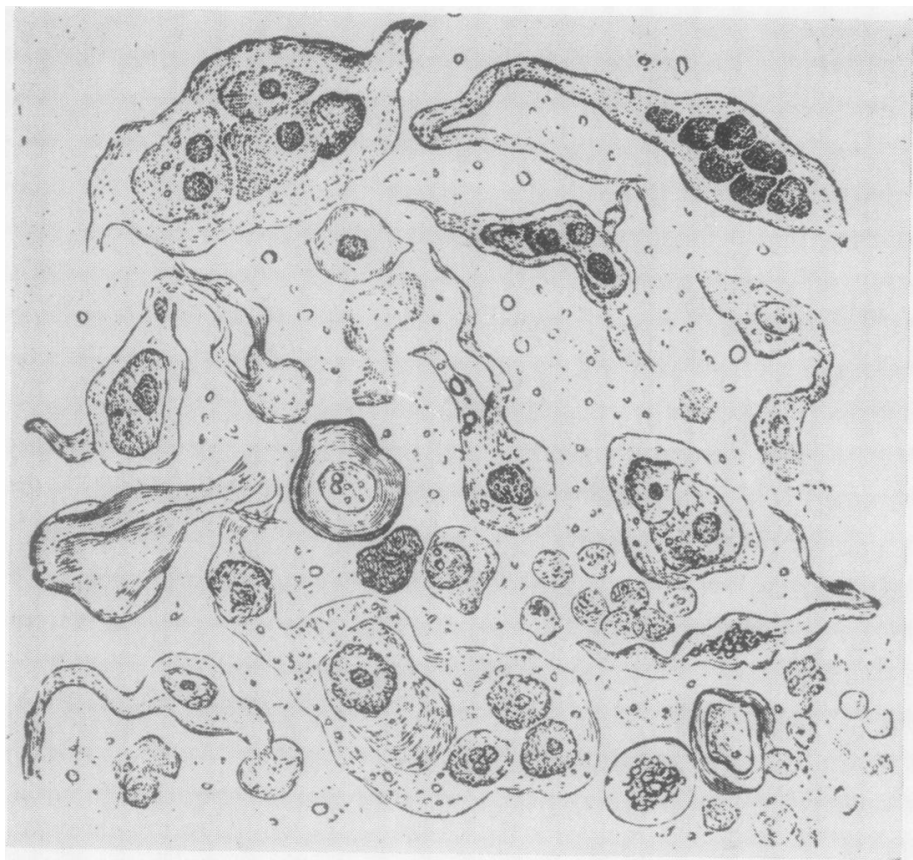

FIG. 4.-Beale's illustration (1878) of cells desquamated and found in the urine from a case of cancer of the uterus. Forms similar to these are found in smears from patients with squamous-celled growths.

FIG. 5.-Beale's illustration (1878) of cancer cells in the sputum Although working 20 years after Virchow he has not fully accepted the cell theory. His caption reads:

"Various forms of the socalled cancer 'cells' in sputum. Many of these bodies are clearly not ' cells,' but fragments of a mass containing nuclei, or small masses of bioplasm irregularly scattered through it. At $p$ is represented a piece from the lower part of which the nuclei and portions of the mass surrounding them have been broken off, leaving cupshaped cavities in which they were lodged."

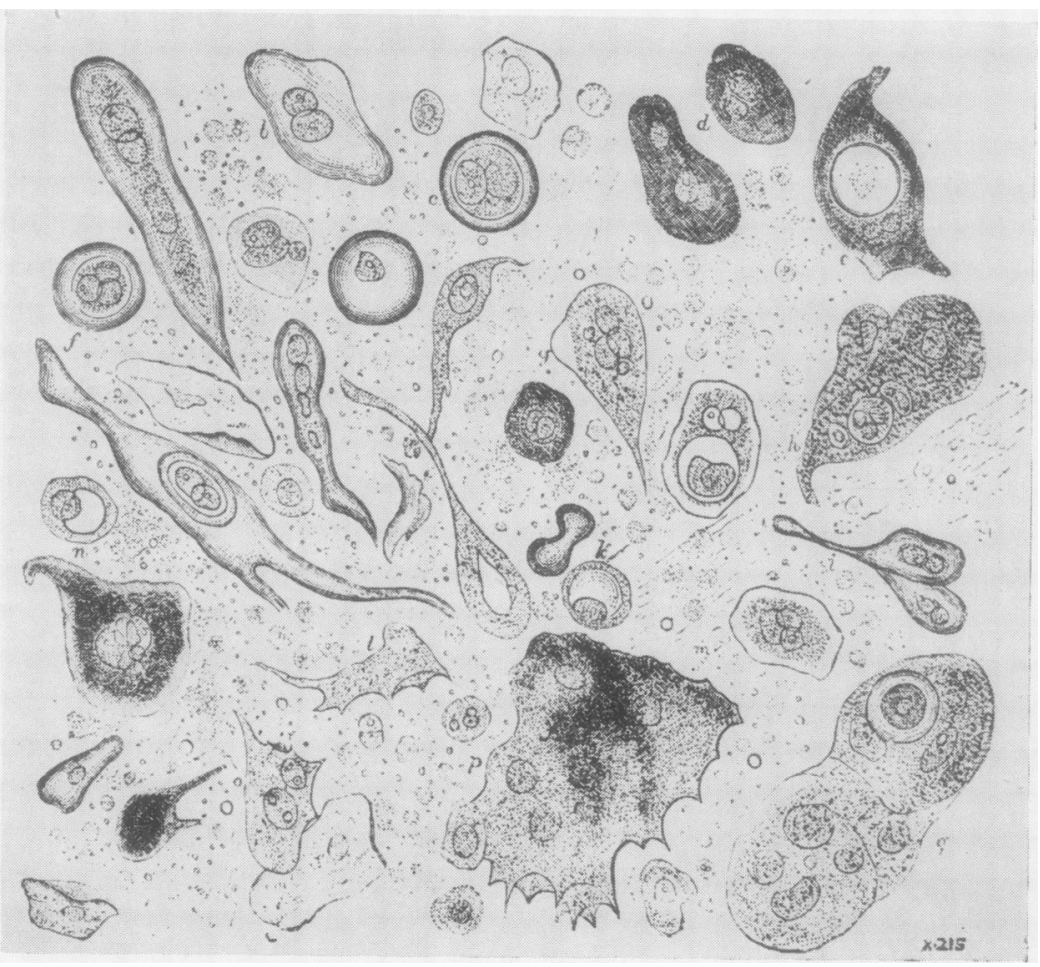




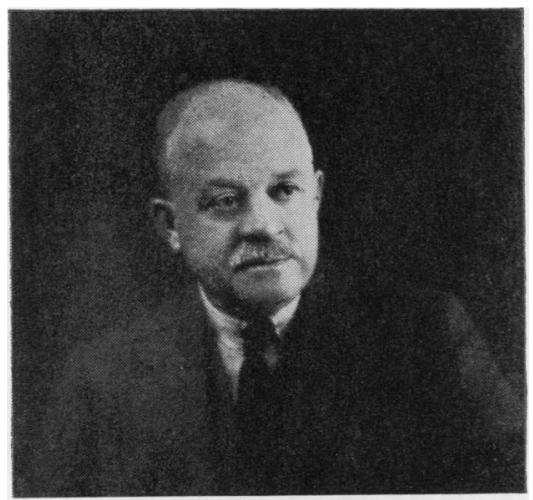

FiG. 6.-L. S. Dudgeon (1876-1938).

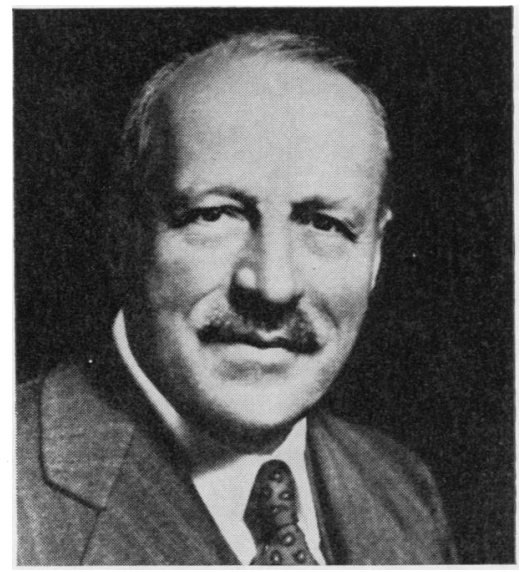

FIG. 7.-G. N. Papanicolaou (born 1883).

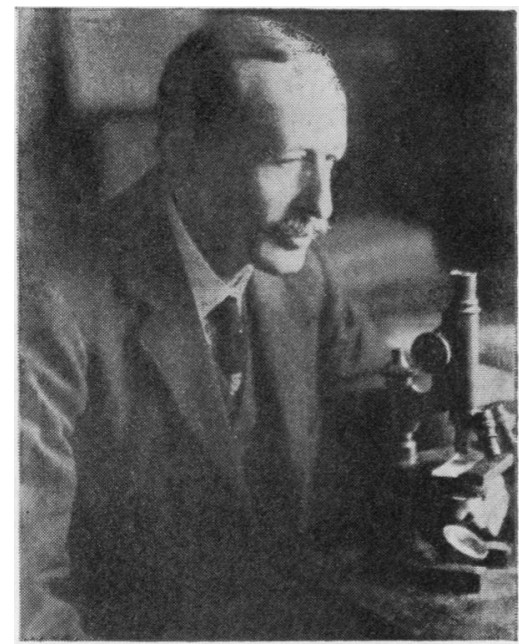

Fig. 8.-James Ewing (1866-1943).

its invasive properties, but fails when high-power detail is necessary. The method of frozen section was used freely and successfully by E. H. Shaw (1910, 1923), who reports more than 1,000 cases and first aided a surgeon in this manner in Yeovil, Somerset, in 1899. Shaw took under five minutes to make his diagnosis, the same time as is required to-day.

Those of us who practise both histology and cytology have no difficulty in seeing in every case how the appearances in the latter are a consequence of the former. The great oncologist, James Ewing, of the Memorial Hospital, New York (Fig. 8), stimulated the study of aspiration biopsy, and papers on this subject were published from the Memorial Hospital by Martin and Ellis in 

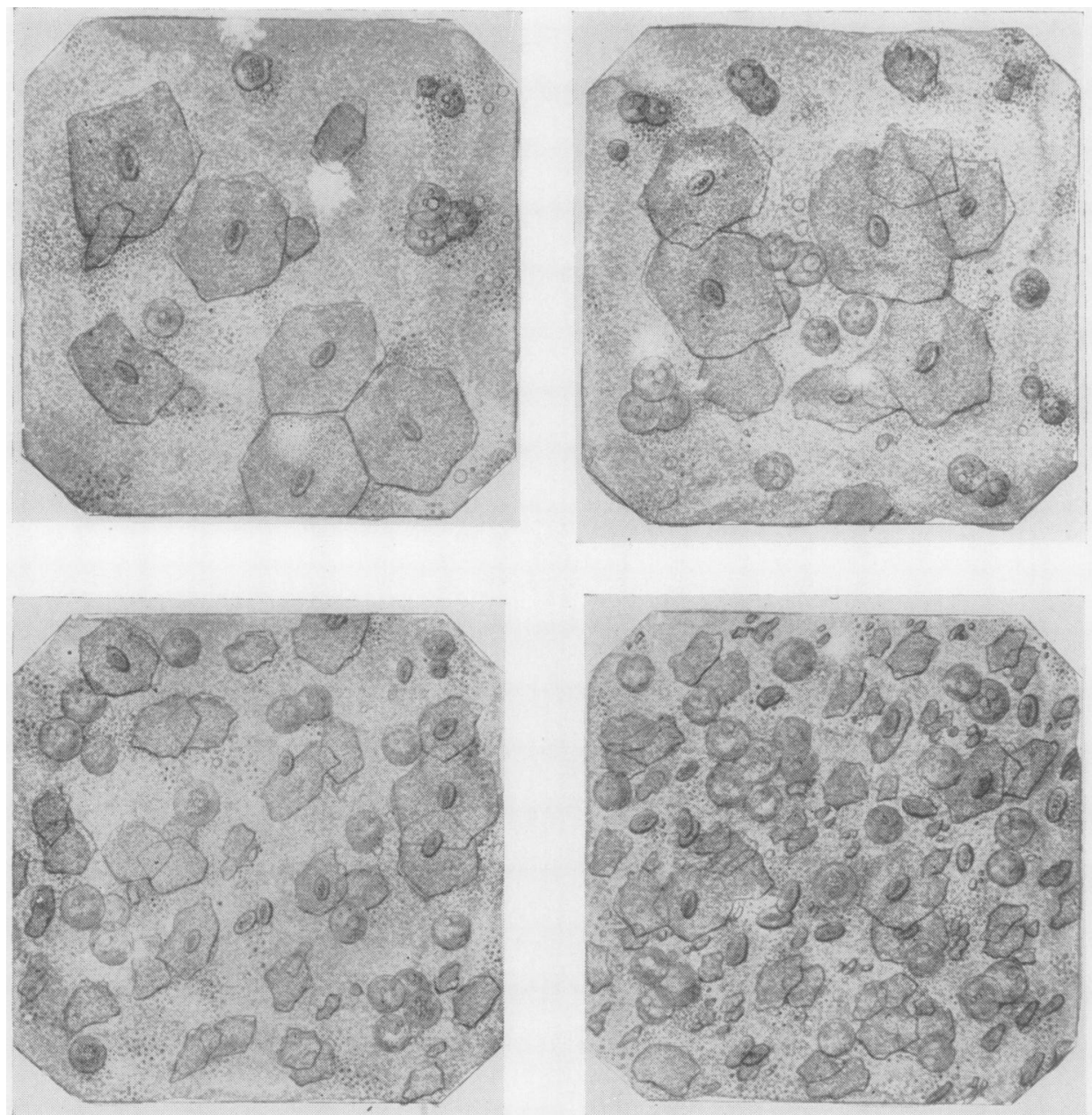

Fig. 9.-Drawings by Pouchet (1847) of the cytology of the intermenstrual phase in women. The first four figures represent the condition two, four, six, and 10 days after the cessation of menstruation.

trated the bladder. Five years before his death he developed vesical calculi which were removed by Dr. Roy B. Henline. Afterwards Ewing examined the centrifuged deposit of his urine many times and ultimately found cancer cells on three occasions. Prostatic cancer was suspected, but Ewing knew the cell he was looking at, and cystoscopy before a contemplated prostatectomy showed a small fundal carcinoma. At operation the bladder wall was too friable for satisfactory removal of the carcinoma and Ewing was returned to his bed. Two days later Dr. Stewart, pathologist to the Memorial Hospital, knew the highly malignant nature of the tumour. He discussed this with Dr. Ewing Jr., and they decided that when Ewing asked to see his section they would substitute one from a much less malignant bladder tumour. Two days later he asked for his slides and the false ones were shown him. His son was in the room at the time. After looking at the sections for two or three minutes Ewing said: "Boy, what are you trying to do to me? You must be naive to send me these sections. They are not mine. I know, because I have already seen the type of cell associated with my type of bladder cancer. Now go and get me my own slides." Dr. Ewing Jr. then says: "Of course, the only thing Dr. Stewart and the rest of us could do was to hand him the proper sections. After looking at them, he was well satisfied." The cytological diagnosis he had made during the preceding eight or 10 months corresponded to the histology. 
Papanicolaou's (Fig. 7) interest in cytology arose from a study of the cyclic changes in guinea-pigs (Stockard and Papanicolaou, 1917). Earlier studies (Fig. 9) along the same lines, both macroscopic and microscopic, had been made by Pouchet in 1847 in Rouen. Allen and Doisy (1923) used this oestrogenic response of vaginal epithelium to isolate the oestrogenic hormone from the fluid in ovarian follicles. In 1923 Papanicolaou extended these animal studies to women at the Women's Hospital of New York City and before long realized that he could recognize carcinoma cells. He reported these studies in 1928. Unfortunately the general opinion then was that these cytological findings were superfluous and he abandoned the work for further studies on some of the sex hormones (Papanicolaou and Shorr, 1936; Papanicoloau, Ripley, and Shorr, 1939 ; Papanicolaou, 1955). Later the studies on cancer of the uterus were resumed more exhaustively with Traut, and the result of three years' work was published in 1943 in the monograph which began the world-wide acceptance of gynaecological cytology although the opposition of large numbers of pathologists did not end with this publication. Opposition has now almost disappeared as a con- sequence of the good results obtained in practice by centres scattered widely over the world and the demonstration of a histological basis.

The development of a histologically unjustifiable nomenclature is one of the unfortunate consequences of the opposition to cytology by histopathologists. When stimulated by oestrogens the stratified squamous epithelium of the cervix and vagina responds by deposition of glycogen in the cytoplasm of all cells except the deepest and the nuclei then become small, central, and pyknotic. Many cytologists are now calling this process cornification. True cornification is often found in the cervix and vagina in women with prolapse. It begins with the development of a stratum pigmentosum and stratum corneum over the capillary loops of the corium and in more advanced lesions these patches coalesce. Squames shed from the cornified patches naturally have no nucleus. On page 238 of their 1917 paper Stockard and Papanicolaou describe them correctly:

"There are, however, to be seen, particularly toward the end of the first stage, a certain number of elongate, cornified cells without nuclei, which are desquamated from the more external parts of the vagina."

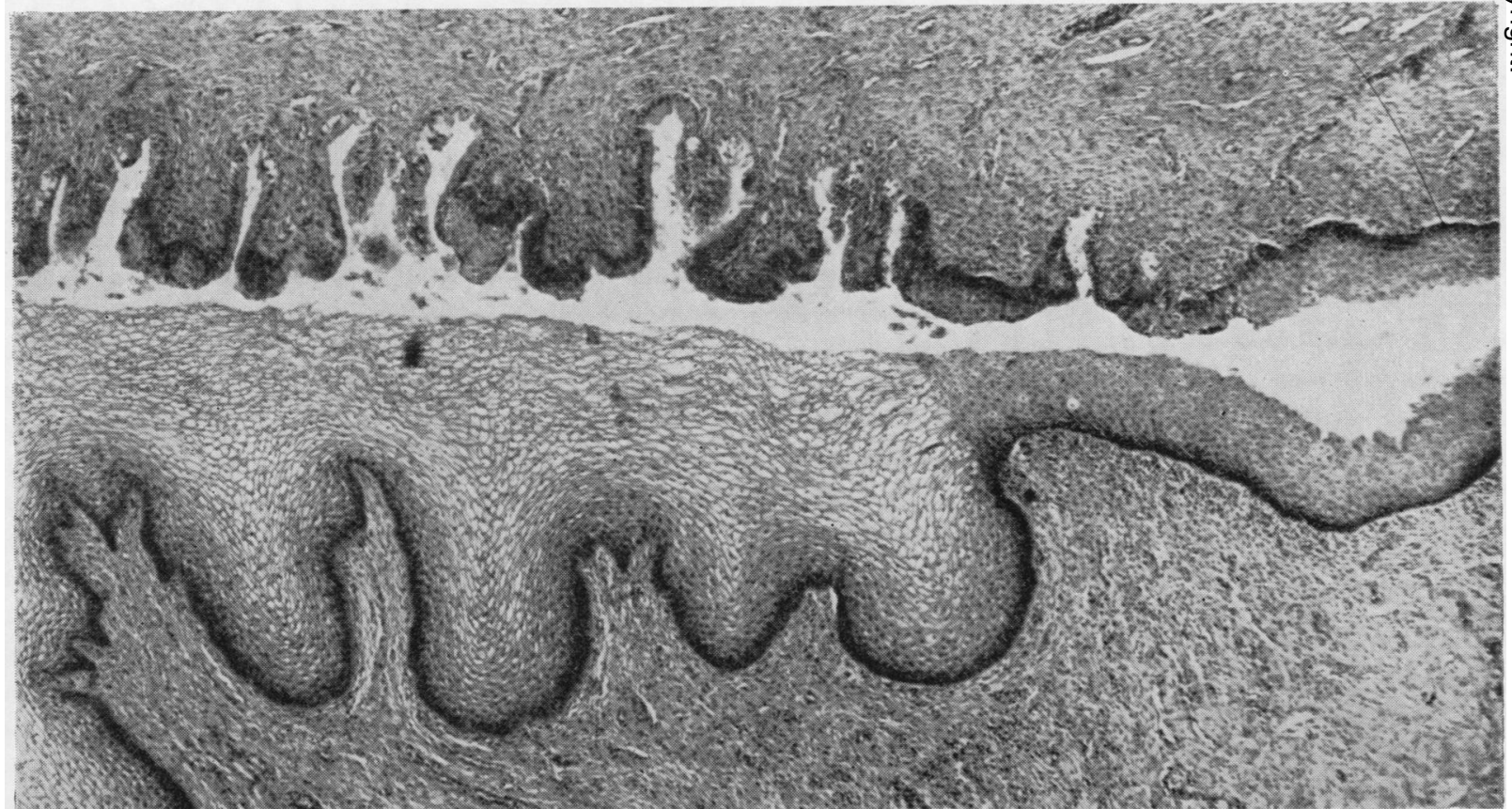

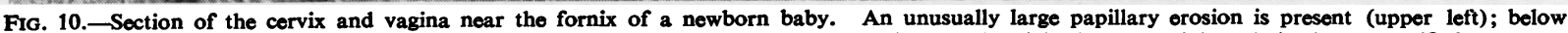

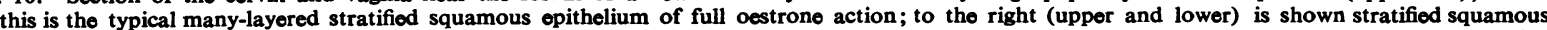

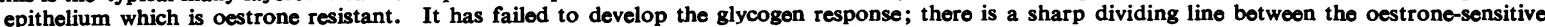

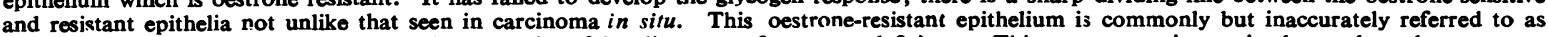

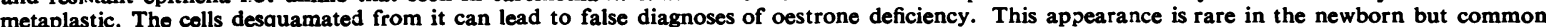
in later life. Haematoxylin and eosin. $\times 40$. 
Basal cells cannot desquamate naturally and are not found in vaginal pool smears. The cells many cytologists call basal are from an epithelium inadequately stimulated by oestrone, so histologically they appear different from those of the fully stimulated epithelium. Embryologists and gynaecological pathologists are familiar with many varieties of squamous metaplasia and oestroneresistant squamous epithelium in the cervix and vagina, but many of these appearances are little understood and are inadequately considered cytologically (Fig. 10).

Histology becomes a much more interesting subject when it is correlated with cytology. This relationship will be considered more particularly in the bronchial mucus and in carcinoma in situ of the uterus. It is important in all regions, however. For the stomach Schade's (1956) studies of chronic antral gastritis should be referred to. The best pre-operative method of diagnosing carcinoma of the prostate is cytological, and the findings after stilboestrol therapy have a histological

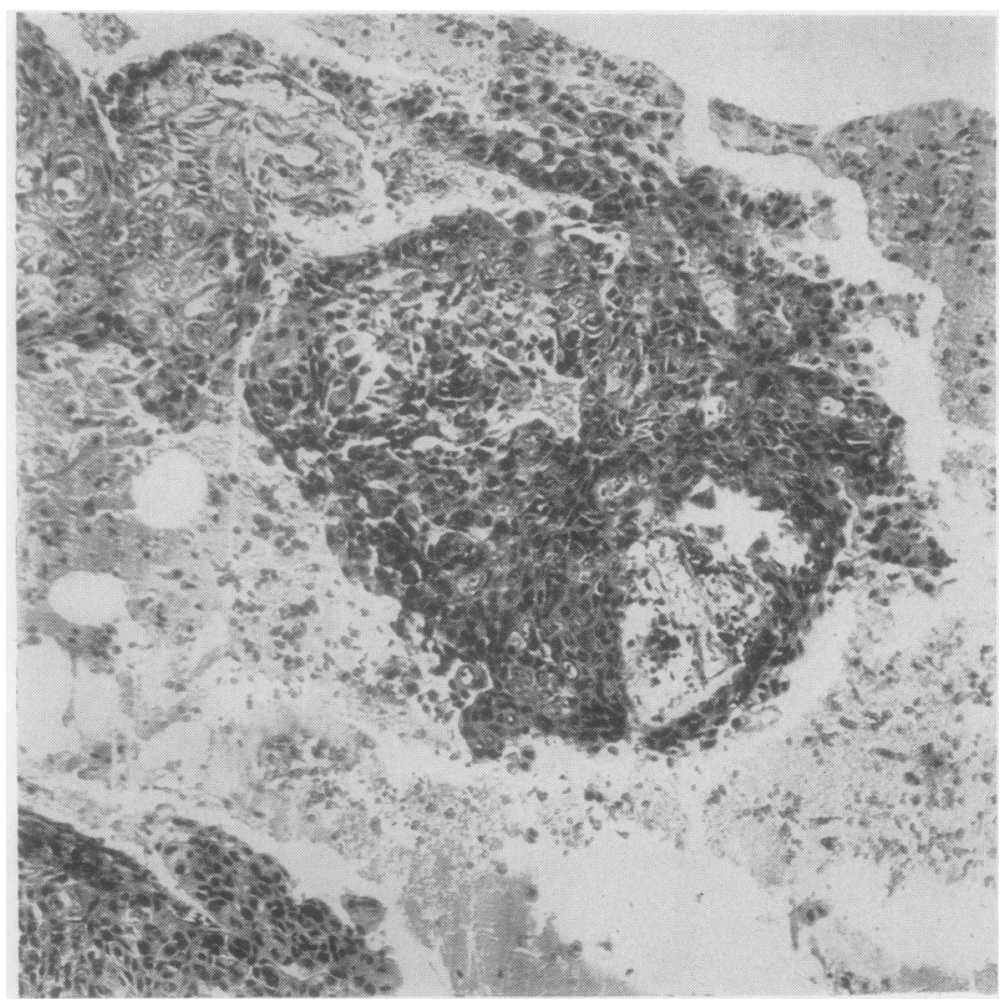

FIG. 11.- Large fragments of squamous-celled carcinoma demonstrated by histological section of the mucus removed in a pure state at bronchoscopy. Many of those were present and practically all were diagnostic and better than the fragments obtained by deliberate biopsy. This must be considered superior to the cytological method, but it is not recommended as a screening method for the sputum. Haematoxylin and eosin. $\times 150$.
TABLE I

COMPARISON OF SPUTUM, TRAP SPECIMEN, AND BIOPSY (174 CASES)

\begin{tabular}{llll|c|c|c}
\hline & & & & Positive & Negative & Not Done \\
\hline Sputum & $\ldots$ & $\ldots$ & $\ldots$ & 21 & 83 & 70 \\
Trap cytology & $\ldots$ & $\ldots$ & $\ldots$ & 54 & 96 & 24 \\
By histology & $\ldots$ & $\ldots$ & $\ldots$ & 62 & 58 & 54 \\
Biopsy.. & $\ldots$ & $\ldots$ & $\ldots$ & 57 & 38 & 79 \\
\hline
\end{tabular}

Sputum positive, other investigations negative $\quad \ldots \quad \ldots \quad \ldots 5$ cases $\begin{array}{llll}\text { Trap specimen positive, other investigations negative } & \ldots & 16 & , \text {, }\end{array}$

25 known cases of cancer of the lung among the 85 negatives:

Sputum and trap specimen examined $\begin{array}{llll} & \ldots & \ldots & 2\end{array}$,

Trap specimen only examined

Trap and biopsy specimens examined trap, and biopsy specimens examined $50 \%$ with cancer proved by biopsy alone

basis (Peters and Franck, 1952 ; Bamforth, 1953; Fergusson and Gibson, 1956). Research is needed to obtain more consistent results when tumours of the bladder are present, and there is no field in which it is more important for the cytologist to be familiar with the histology of the lesions. Breast cytology can be dangerously misleading if reported on by someone not skilled in breast histology.

For various reasons the results with sputum cytology at the Derbyshire Royal Infirmary (G.R.O.) are not as good as those reported by Dudgeon and Wrigley in 1935, but because of the dramatic results obtained at regular intervals we feel the service must be offered to the clinicians in spite of many disappointments. The results with bronchial mucus are much more satisfactory, and nowhere has the ability to command histological methods as well given such a rich reward. Table I shows that bronchial biopsy alone gave the diagnosis in only half the patients with bronchogenic carcinoma, but the figure was raised to $78 \%$ by adding a full study of the bronchial mucus.

The bronchial mucus must be obtained in its pure state by the thoracic surgeon, and because of its method of collection it is referred to as the "trap specimen." It varies 
FIG. 12.- Innumerable Trichomonas vaginalis demonstrated in the histological section of the vagina of a baby dying at 27 days. The elliptical nucleus is well shown in many of the parasites (marked $T$ ). The stratified squamous epithelium of the vagina is seen in the lowor right part. Haematoxylin and eosin. $\times 600$.

in amount and must $\mathrm{never}$ be diluted with saline. At first it was examined cytologically only; but quite early, rather than waste the residue, some was fixed in Zenker's solution and studied histologically. In many cases the results of the histology of the trap specimen are extraordinary, numerous perfectly preserved carcinoma fragments being present (Fig. 11). The results in these patients were so very good that it was thought there was no need to take biopsies. However, when the full series was studied it was found that in 13 cases with a positive biopsy there was a negative result for the trap specimen. The opposite finding of negative biopsy and positive trap specimen was verified 16 times. The conclusion is not that one method is better than another, but that most diagnoses are proved when all methods are employed. Some ob-

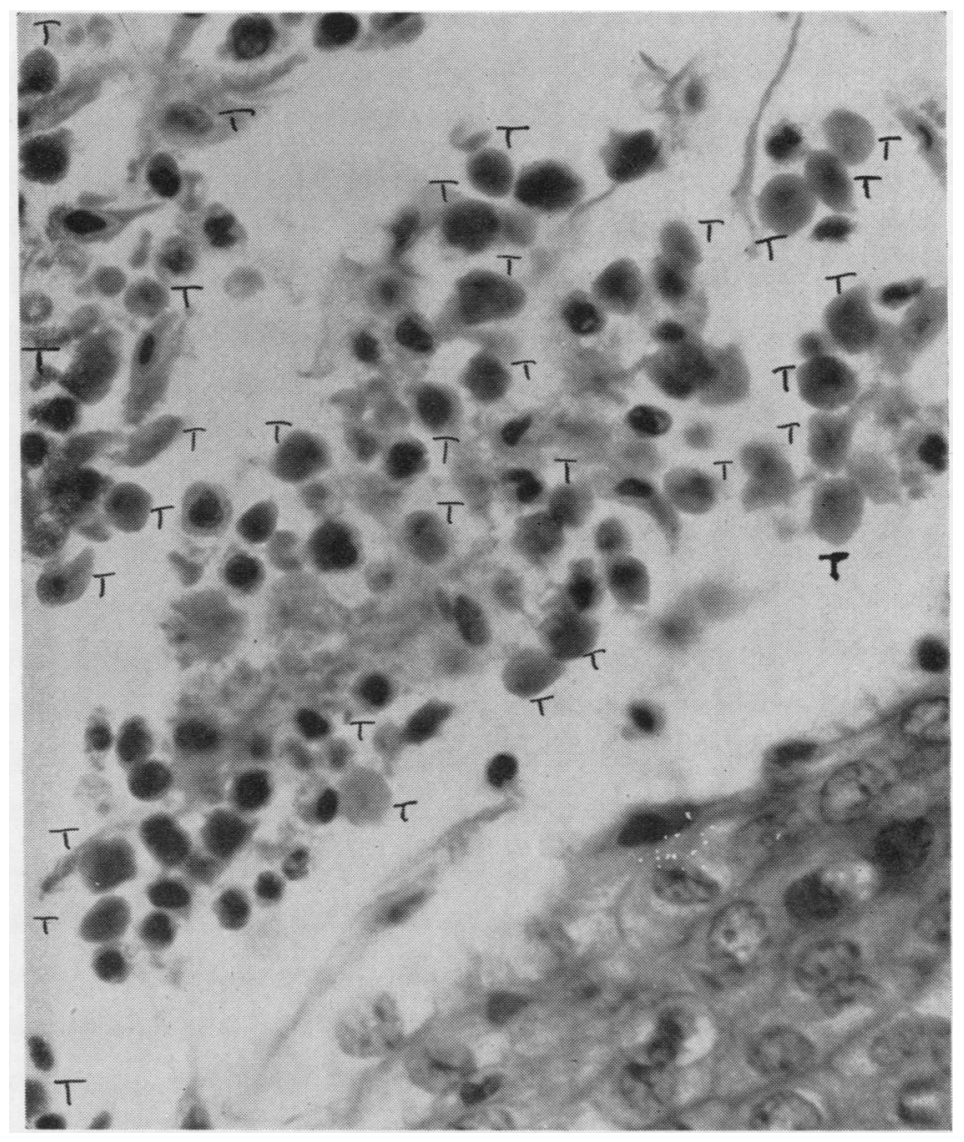

TABLE II these, but we do not expect to be able to diagnose all cases of carcinoma of the lung.

Excellent results follow the use of all methods in cancer of the uterus. A review of the past 463 cases of invasive carcinoma of this organ in Derby shows that by one means or another all the patients were diagnosed. There is no known case in which inspection by the gynaecologist, biopsy, and cytology all gave negative results. Some women had negative results to one or two of these methods but none to all three. These results with photomicrographs are given elsewhere for both the bronchial mucus and the uterus (Osborn, 1956a and $b ; 1958$ ).

Table II shows the Derby cases of carcinoma in situ of the uterus. In the majority the first stage in the diagnosis was cytological. Some had negative smears, but the main reasons for this were poorly taken smears and a very small or incompletely developed lesion. Some pathologists would call the appearances those of basal hyperplasia and others carcinoma in situ. The average
AGES OF 87 CASES OF CARCINOMA IN SITU OF CERVIX

\begin{tabular}{ll|r|r|r|r|r|r|r}
\hline & $20 \mathrm{~s}$ & $30 \mathrm{~s}$ & $40 \mathrm{~s}$ & $50 \mathrm{~s}$ & $60 \mathrm{~s}$ & $70 \mathrm{~s}$ & $80 \mathrm{~s}$ \\
\hline $\begin{array}{ll}87 \text { in situ } \\
\text { 150 invasive }\end{array}$ & $\cdots$ & 13 & 26 & 27 & 16 & 4 & 1 & 0 \\
\hline
\end{tabular}

Average age 39 years 11 months, range 22-72 years; of invasive 54 years, range $27-83$ years

A, Preliminary cytology only B, Preliminary biopsy only $\begin{array}{lllll} & & & & \end{array}$

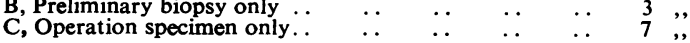

\section{CYTOLOGY OF THE 77 CASES}

$$
\begin{aligned}
& 39 \text { cancer cells } \\
& 19 \text {," }, " \text { probably present } \\
& 67 \text { possibly present }
\end{aligned}
$$
in situ all had negative cytology.

Two cases were of the cervical stump after subtotal hysterectomy.

\section{TREATMENT}

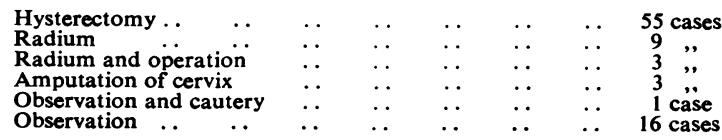

$\begin{array}{llllll} & \ldots & \text {. } & \text {. } & 10 \text { cases }\end{array}$

Six cases in transitional stage of basal hyperplasia to carcinoma 
age of these women is 14 years less than the average for those with invasive squamous-celled growths, thus giving a long time for diagnosis in the gynaecological clinics. It is a great pity that we are still not diagnosing the majority of these cases which are in women not attending hospitals or in women attending hospitals lacking a service in cytology. Because these women should all remain well there can be no greater service rendered by cytology. The condition is fully considered elsewhere (Osborn, 1958).

It is impossible to consider the value of cytodiagnosis in all branches of hospital work, as it has given rise to unexpected findings in many fields, so two will be mentioned in conclusion. A number of venereologists have reported that infection with Trichomonas vaginalis disappears at the menopause. The best method of diagnosing this infection is cytological. By this means it was known that in the Derby gynaecological clinics the maximum incidence is about the time of the menopause and cases have been recognized in women in the 70 s and 80 s. Mr. H. R. M. Richards was, therefore, asked to record the age incidence in the V.D. Department, and he found a maximum incidence around the age of 20 (Osborn, 1956b). The young women are not used to attending gynaecologists, because, knowing how the infection has arisen, they mostly go to the V.D. Department. The full picture of this disease is not obtained from one hospital department. The second unexpected result of interest was in a baby girl dying on the 27th day of life. It is customary to examine the uterus and vagina in all neonatal female deaths to see the range of epithelial appearances (Fig. 10) and to obtain information on congenital erosions. The section from this baby girl (Fig. 12) showed great numbers of Trichomonas vaginalis in the vagina. Smears from the baby's mother were obtained and, as expected, were shown to contain Trichomonas vaginalis also.

What then should be the place of diagnosis from cells to-day? It is the same as it was $\mathbf{1 0 0}$ years ago, and has been in a limited number of laboratories since then. It is only one way of looking at a diagnostic problem, but when correlated with other diagnostic methods it is always interesting and often of the greatest value, and may lead to the correct diagnosis of cancer when inspection and biopsy fail. Cytology should therefore not be confined in a special department of its own but should be practised in the general laboratory. If cytology reveals some of the limitations of inspection and biopsy, these in their turn reveal some of the limitations of cytology, and most diagnoses are made when all methods are used.

We are greatly indebted to Mr. T. J. Shields, Librarian of the British Medical Association, and to Dr. F. N. L. Poynter, Librarian of the Wellcome Historical Medical Library, also to Dr. G. N. Papanicolaou and Dr. James H. Ewing for their assistance. The photomicrographs were taken by Mr. J. S. Fayers.

\section{REFERENCES}

Allen, E., and Doisy, E. A. (1923). J. Amer. med. Ass., 81, 819. Bamforth, J. (1953). Practitioner, 171, 244.

Beale, Lionel S. (1878). The Microscope in Medicine, 4th ed. J. \& A. Churchill, London; Lindsay and Blakiston, Philadelphia.

Corti, A. (1851). Z. wiss. Zool., 3, 109.

Donné, A. (1836). C. R. Acad. Sci. (Paris), 3, 385.

Dudgeon, L. S., and Barrett, N. R. (1934). Brit. J. Surg., $22,4$. and Patrick, C. V. (1927). Ibid., 15, 250.

and Wrigley, C. H. (1935). J. Laryng., 50, 752.

Dürck, Hermann (1904). Atlas and Epitome of General Pathologic Histology, ed. L. Hektoen. W. B. Saunders, Philadelphia, New York, London.

Fergusson, J. D., and Gibson, E. C. (1956). Brit. med. J., $1,822$.

Gerlach, J. (1858a). Mikroskopische Studien aus dem Gebiete der meinschlichen Morphologie. Enke, Erlangen.

(1858b). Wiss. Mitth. phys. med. Soc. Erlangen, $1,5$.

Gierke, H: (1884). Z. wiss. Mikr., 1-100, 62, 372-408, 497-557. - (1885). Ibid., 2, 13-36, 164-221.

Goeppert, H. R., and Cohn, F. (1849). Bot. Ztg., 7, 665-673, 681-691, 697-705, 713-719.

Hartig, T. (1854a). Ibid., 12, 553. (1854b). Ibid., 12, 574 .

- (1854c). Ibid., 12, 893 .

Hill, J. (1770). The construction of Timber, from its early growth: explained by the microscope, and proved from Experiments in a great Variety of kinds. London. Quoted by Conn. H. J., great Variety of kinds. London. Quoted by Conn, H.
History of Staining. Biotech. Publications, U.S.A., 1948.

History of Staining. Biotech. Publications, U.S.A., 1948.
Leeuwenhoek, Anthony van (1719). Epistolae physiologicae super compluribus naturae arcanis (opera omnia, T.3): Delphis. Epistola XI, 98-111.

Martin, H. E., and Ellis, E. B. (1930). Ann. Surg., 92, 169.

(1934). Surg. Gynec. Obstet., 59, 578.

Osborn, G. R. (1956a). Proc. roy. Soc. Med., 49, 246.

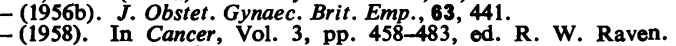
(1958). In Cancer,

Papanicolaou, G. N. (1928). New Cancer Diagnosis. Proc. III Race Betterment Conference, p. 528. (1955). Tex. Rep. Biol. Med., 13, 901.

- Riploy, H. S., and Shorr, E. (1939). Endocrinology, 24, 339. and Shorr, E.' (1936). Amer. J. Obstet. Gynec., 31, 806.

- and Traut, H. F. (1943). Diagnosis of Uterine Cancer by the Vaginal Smear. Tho Commonwealth Fund, Now York

Peters, H., and Frank, I. N. (1952). Surg. Gynec. Obstet., $94,69$.

Pouchet, F.-A. (1847). Théorie Positive de L'Ovulation Spontanée et de la Fécondation des Mammiferes er de L'Espèce Humaine. J.-B. Baillière, Paris.

Schade, R. O. K. (1956). Gastroenterologia (Basel), 85, 190.

Shaw, E. H. (1910). Lancet, 2, 939.

(1923). Ibid., 1, 218.

Stockard, C. R., and Papanicolaou, G. N. (1917). Amer. J. Anat., 22, 225 . 